Karolina Galewska

Instytut Filologii Polskiej, Uniwersytet im. Adama Mickiewicza w Poznaniu

\title{
Wielka sztuka niewielkiego narodu: Polska na tle kontaktów literackich Chin z Europą Środkowo-Wschodnią
}

Gdy patrzę na przykład wielu „gnębionych narodów”, takich jak Żydzi, Polacy czy Czesi, którzy utracili suwerenność, a jednak wcią̇ moga poszczycić się wtasna nieśmiertelną sztuka, to ośmielam się wierzyć, że naród chiński, mimo iż zmierza do bankructwa i podległości obcym mocarstwom, również będzie mógł szczycić się taka twórczościa!

Mao Dun, Wrażenia z zeszłego roku i plany na przyszły

Idea stworzenia języka uniwersalnego, przyświecająca badaczom, takim jak Ludwik Zamenhof, nigdy nie została w pełni urzeczywistniona. Sztuczne kody językowe nie są w stanie zastąpić naturalnego narzędzia porozumiewania się, choć próby ich wdrożenia świadczą o głęboko zakorzenionym w człowieku pragnieniu swobodnej komunikacji, czyli symbolicznego powrotu do czasów niezakłóconej współpracy przy wznoszeniu wieży Babel. Jak mawiał Platon: „[...] bogowie najbardziej uszczęśliwiliby ludzkość, gdyby obdarowali ją jednym wspólnym językiem" [Kulczycki 2007: 68]. Brak formalnego medium ponadnarodowej wymiany myśli rekompensuje literatura jako ośrodek dialogu pomiędzy zróżnicowanymi geograficznie, politycznie i kulturowo nacjami.

Postrzeganie literatury jako swoistego kanału komunikacji towarzyszyło twórcom serii Historia Kontaktów Literackich między Chinami a Zagranicą. Opis kontaktów literackich stanowi w ujęciu chińskich literaturoznawców wieloaspektową rekonstrukcję dziejów interakcji określonych narodów w perspektywie historycznej, politycznej i kulturowej. Imponujące rozmachem przedsięwzięcie, złożone z 17 tomów poświęconych poszczególnym 
regionom świata, jest owocem rozwoju oraz unowocześnienia badań nad relacjami literatury rodzimej i obcej w Chinach. Autorzy dążyli do przyjęcia „dialogowej” metody opisu, a więc równoczesnego oglądu obu stron wymiany intelektualnej i ich wzajemnych wpływów. Ich celem było „objaśnianie dwukierunkowe”, skoncentrowane nie tylko na omówieniu tłumaczeń i recepcji dzieł, lecz także obejmujące kwestie poznania i wzajemnego oddziaływania twórczości danych nacji [Ding, Song 2020: 50].

Nacisk na dwukierunkowość procesu wymiany literackiej wynika z przekonania o konieczności wypracowania nowej narracji komparatystycznej, uwolnionej od jednowymiarowej perspektywy państw-hegemonów oraz dominacji świadomości euroamerykańskiej [Ding, Song 2020: 29, 37]. Choć sfera obiegu dzieł i ich tłumaczenia jest naznaczona oczywistymi nierównościami, w założeniu każdy naród uczestniczy w kształtowaniu literatury światowej [Ding, Song 2020: 45]. Twórcy serii starali się zarysować możliwie pełny obraz interakcji kulturalnych pomiędzy Chinami a innymi państwami, uwzględniający głos nacji, których twórczość stanowi peryferie imaginarium literatury zagranicznej. $Z$ tego powodu tom Chiny i Europa Środkowo-Wschodnia. Historia kontaktów literackich, wydany w 2020 roku przez Wydawnictwo Akademickie Dialog, ma charakter publikacji przełomowej. Jego autorzy podjęli się scalenia dorobku przedstawicieli kilkunastu filologii, stanowiącego marginalny obszar chińskich badań literaturoznawczych.

Tom poświęcony środkowo-wschodniej części Europy wyróżnia się na tle pozostałych z powodu stosunkowo ubogiej wymiany dóbr artystycznych Chin z tym rejonem świata (w porównaniu np. do kontaktów chińsko-japońskich, chińsko-rosyjskich czy chińsko-brytyjskich i amerykańskich). Na jego specyfikę wpływa również syntetyczny opis relacji z 16 odrębnymi państwami, traktowanymi w chińskiej polityce jako jeden region ${ }^{1}$. Podkreśla się, że kraje te łączy przejście kompleksowej transformacji ustrojowej oraz długa tradycja przyjaźni i stosunków dyplomatycznych z Chińską Czechy, Estonię, Litwę, Łotwę, Macedonię Północną, Polskę, Rumunię, Serbię, Słowację, Słowenię i Węgry. Współpraca Chin i krajów Europy Środkowo-Wschodniej określana jest mianem „współpracy grupy $16+1$ ”. 
Republiką Ludową [Ding, Song 2020: 63], nieobarczonych historycznymi urazami i konfliktami interesów [Ding, Song 2020: 67]. Jak zaznaczają chińscy badacze, są to kontakty dobrowolne i równoprawne, nieuwikłane w układy silniejszego i słabszego [Ding, Song 2020: 91], czego nie można powiedzieć o skomplikowanej przeszłości Dalekiego Wschodu i europejskich mocarstw, które w XIX wieku uczyniły Państwo Środka obiektem imperialnych dążeń.

Poszczególnym krajom europejskim poświęcone zostały w książce odrębne fragmenty, stanowiące każdorazowo część większych rozdziałów, uporządkowanych według klucza chronologicznego. Wymiana literacka została omówiona na tle szeroko rozumianych kontaktów dyplomatycznych, jej rekonstrukcję autorzy zaczynają zatem od pierwszych kontaktów między Chinami a Europą Środkowo-Wschodnią, uwzględniając również archaiczne wyobrażenia i szczątkowe wzmianki w najstarszych tekstach. Osadziwszy narrację w kolejnych okresach historii Chin, dokonano przeglądu wypraw podróżników, ich relacji, postaci, które przyczyniły się do zacieśnienia więzi między omawianymi krajami, tekstów zawierających różnego rodzaju odniesienia do obcej nacji, najważniejszych tłumaczeń oraz badaczy zajmujących się językiem i literaturą danych rejonów. Wszystkie te aspekty ujęto dwukierunkowo, a więc analizie poddano zarówno wpływy kultury państw europejskich oraz obecność ich obywateli w Chinach, jak i oddziaływanie chińskiej kultury i jej przedstawicieli na kraje Środkowo-Wschodniej Europy.

Potraktowanie grupy różnorodnych narodów jako wspólnego punktu odniesienia uniemożliwia stworzenie pełnego i analogicznego opisu ich relacji z Państwem Środka. Stosunki te nie są rozwinięte $w$ takim samym stopniu, a dodatkowe ograniczenie stanowi niewystarczająca liczba opracowań i tłumaczeń umożliwiających odtworzenie historii kontaktów między określonymi nacjami. $\mathrm{Z}$ tego powodu publikacja zawiera niewiele informacji na temat państw bałtyckich czy dawnej Jugosławii². Polska z kolei zajmuje

2 Jako że informacje dotyczące tych regionów są szczątkowe, a autorzy dość swobodnie omawiają określone kwestie w odniesieniu do wybranych państw, czytelnik niejednokrotnie zadaje sobie pytanie, czy pewne zagadnienia nie zostały 
centralne miejsce w historii wymiany kulturalnej między Chinami a Europą Środkowo-Wschodnią i obok takich krajów, jak Czechy, Węgry i Rumunia, poświęcono jej w opracowaniu najwięcej uwagi.

Polska jest przede wszystkim krajem rozpoznawalnym w Chinach, co, biorąc pod uwagę porównywalną powierzchnię państwa chińskiego i całego kontynentu europejskiego, nie jest kwestią oczywistą. Postaciami kojarzonymi z Europą Środkowo-Wschodnią są głównie Polacy, czyli Mikołaj Kopernik, Maria Curie-Skłodowska i Fryderyk Chopin [Ding, Song 2020: 66]. Polscy zakonnicy odegrali również znaczącą rolę w pierwszych kontaktach Europejczyków z Dalekim Wschodem i rozpowszechnianiu wiedzy o tym rejonie świata. Nasz rodak, Benedykt Polak, przybył do Azji 30 lat przed słynnym podróżnikiem Marco Polo, jako towarzysz i tłumacz papieskiego wysłannika składającego wizytę mongolskiemu chanowi [Ding, Song 2020: 149-150]. Za najważniejszą postać w historii relacji kulturalnych Chin z ludami środkowoeuropejskimi uznaje się Michała Boyma, który wprowadził na Stary Kontynent tradycyjną chińską medycynę [Ding, Song 2020: 176]. Żyjący w XVII wieku misjonarz opisał system społeczny i polityczny, zwyczaje oraz historię Państwa Środka, stworzył jego mapę (Mappa Imperii Sinarum), pierwszy w literaturze Zachodu atlas azjatyckiej flory i fauny (Flora Sinensis), a także pierwszy słownik języka chińskiego dla Europejczyków [Ding, Song 2020: 181-182].

Jezuicka działalność misyjna rozpoczęła bezpośrednią wymianę kulturalną między Chinami a Europą Środkowo-Wschodnią, zainicjowaną pod koniec xvi stulecia. Przedstawiciele Towarzystwa Jezusowego byli wybitnymi uczonymi, propagatorami wiedzy naukowej i cywilizacyjnych osiągnięć Zachodu [Ding, Song 2020: 170]. To dzięki nim do mieszkańców Państwa Środka zaczęły docierać bardziej szczegółowe informacje na temat ziem środkowoeuropejskich. W zbiorowej świadomości Chińczyków Polska pojawiła się jednak dużo później, za sprawą głośnych na arenie międzynarodowej rozbiorów, które relacjonowali także chińscy dyplomaci stacjonujący w Europie w XIX wieku. Myśliciele 
z czasów późnej dynastii Qing byli żywo zainteresowani losami Rzeczpospolitej. Dostrzegali w nich wiele analogii z losem swojego kraju i traktowali je jako rodzaj przestrogi dla Chin ${ }^{3}$ [Ding, Song 2020: 277]. W 1898 roku dygnitarz Kang Youwei przedstawił nawet ówczesnemu cesarzowi traktat dotyczący upadku naszej ojczyzny, ukazujący osobiste zaangażowanie autora w omawiane kwestie.

Kang potraktował Polskę jako wzór negatywny [...]. Chciał w ten sposób zademonstrować konieczność reform edukacji i systemu politycznego i napominał cesarza, „by pomyślał czasami o błędach Polski”. W pełnym emocji tonie zwracał się do władcy: „Ubolewam nad losem Polaków, ale pisząc te słowa, myślę o Chinach i moje łzy spływają na papier, a poła szaty już nimi przesiąkła”. [Ding, Song 2020: 277]

Przykład Rzeczpospolitej miał dowodzić szkodliwości konserwatyzmu elit społecznych i stanowić bodziec do budowy silnego, niezależnego państwa. Sytuacja Polaków była szeroko dyskutowana, o czym świadczą dane statystyczne z chińskiej prasy końca XIX i pierwszej połowy xx wieku. Wśród tekstów poświęconych krajom Europy Środkowo-Wschodniej przeważająca liczba wzmianek dotyczyła Polski

Kiedy na początku xx stulecia inwazja zachodnich imperiów na Chiny przybrała na sile, tamtejsi intelektualiści coraz częściej odwoływali się do doświadczenia podbitych krajów, również jako źródła pozytywnych wzorców męstwa i odwagi. Częścią programu ocalenia narodowego uczyniono hasło „uczenia się z historii podbitych państw”, które oprócz wybranych terytoriów dalekowschod-

Pod koniec XIx wieku Cesarstwo Rosyjskie szukało pretekstów, by sprawować kontrolę nad coraz większymi obszarami północno-wschodnich granic Chin [Ding, Song 2020: 278]. Ponadto od czasu wojen opiumowych „kolonizacyjna agresja zachodnich mocarstw przekształciła Chiny w państwo półkolonialne i półfeudalne" [Ding, Song 2020: 219].

4 Autorzy omawianej publikacji podają nawet konkretne dane. We wskazanym przedziale czasowym Polsce poświęcono 31075 zapisów, Czechom - 19 689, Rumunii - 10 155, a Węgrom - 7831 [Ding, Song 2020: 273]. Warto zaznaczyć, że pierwszą gazetę w Chinach zaczęto wydawać dopiero w 1850 roku z inicjatywy brytyjskiej. 
nich odnosiło się również do Rzeczpospolitej [Ding, Song 2020: 377-378]. Wielokrotnie tłumaczono Wojenna historię upadku polski japońskiego autora Shibue Tamotu i to właśnie zainteresowanie sytuacją polityczną uciśnionych nacji zainicjowało pracę nad przekładami literatury Europy Środkowo-Wschodniej [Ding, Song 2020: 380-383]. Twórczość pisarzy z tego rejonu świata opisywana jest w Chinach za pomocą takich określeń, jak „literatura słabych i niewielkich narodów”, „literatura narodów uciskanych i gnębionych” czy „literatura narodów marginalizowanych” [Ding, Song 2020: 71].

Choć początek wymiany literackiej między Europą Środkowo-Wschodnią a Chinami przypada dopiero na pierwsze dziesięciolecia ubiegłego wieku, twórczość gnębionych narodów miała ogromny wpływ na rozwój literatury chińskiej [Ding, Song 2020: 376, 477]. Zaczerpnięto z niej idee oporu i walki o niepodległość, które nie tylko dominowały w licznie tłumaczonych dziełach, lecz także były wykorzystywane przez rodzimych artystów. Polska przestała być jedynie symbolem politycznego upadku. Stała się również synonimem odwagi, heroizmu i niepokornego ducha przymiotów powstańców. W debacie publicznej wzór do naśladowania stanowiły „gorące serca Polaków i ich umiłowanie wolności” [Ding, Song 2020: 410]. Losy naszej ojczyzny wywarły tak duży wpływ na chińskie społeczeństwo, że w 1904 roku uczyniono je tematem przełomowej opery pekińskiej. Ta tradycyjna forma sztuki, wysoce schematyczna i alegoryczna, została zaprezentowana w zupełnie nowym stylu w ramach inscenizacji Przyczyny rozbioru Polski, stworzonej przez reformatora klasycznej opery Wang Xiaononga ${ }^{5}$ [Ding, Song 2020: 383-384]. Była to pierwsza sztuka owego gatunku wystawiona w zachodnich strojach i oparta na historii innego kraju. Jak podkreślają chińscy literaturoznawcy, „wykorzystywanie polskich wątków w oryginalnej twórczości jest zjawiskiem charakterystycznym dla wczesnego okresu chińskich kontaktów literackich z zagranicą"6 [Ding, Song 2020: 388 ]. i dotyczyło, co zaskakujące, wojny Polski z Turcją [Ding, Song 2020: 385].

6 Autorzy opracowania wspominają kilkakrotnie o popularności dramatu Leopolda Kampfa $W$ Przededniu, opartego na historii zamachu na cara, i jego wplywie na wielu pisarzy. Sztukę uważa się za pierwsze dzieło z Europy Środkowo- 
Początkowo kojarzona głównie za sprawą sytuacji politycznej, z czasem Polska zaistniała w Państwie Środka także jako ojczyzna pisarzy krzewiących ducha tyrteizmu i głoszących wielkość narodu. Przyczynił się do tego zbiór esejów Lu Xuna O sile poezji demonicznej z 1908 roku, zawierający pierwsze omówienie polskiej literatury romantycznej?

Tłumaczenie utworów zaangażowanych, podejmujących tematy narodowowyzwoleńcze, było wówczas priorytetem inteligencji, która chciała wzniecić bunt przeciwko opresyjnym rządom Mandżurów. Jak wspominał Lu Xun, „sytuacja w Chinach przypominała sytuację $\mathrm{w}$ Polsce, więc w polskiej poezji łatwo można było odnaleźć uczucia podobne do naszych" [Ding, Song 2020: 423].

Szczególne zainteresowanie autora pionierskiej publikacji naszym krajem znacząco wpłynęło na rangę polskiej twórczości w Chinach. Lu Xun jest bowiem uznawany za ojca chińskiej literatury współczesnej i traktuje się go, obok Mao Zedonga, jako jedną z postaci współtworzących panteon wielkich twórców potęgi Państwa Środka ${ }^{8}$. Tłumaczenie zagranicznych dzieł było misją pisarza, który postawił sobie za cel reformę chińskiej kultury [Ding, Song 2020: 391-392]. W owym czasie działalność translatorska miała przyczynić się do kształtowania świadomości narodowej, wzmocnienia pozycji państwa, otwarcia Chin na świat i zmniej-

-Wschodniej przełożone na chiński; był to jednak utwór napisany w języku niemieckim [Ding, Song 2020: 385-390].

Głównym celem dzieła było „przedstawienie sylwetek rosyjskich, polskich i węgierskich «poetów zemsty» kontynuujących romantyczną tradycję Byrona i Shelleya" [Ding, Song 2020: 393]. Literaturę polską reprezentują w nim Adam Mickiewicz, Juliusz Słowacki i Zygmunt Krasiński, a węgierską - Sándor Petőfi.

8 Lu Xunowi przypisuje się największy wkład w ukształtowanie współczesnego języka literackiego [Ding, Song 2020: 21-22]. Nad przekładami twórczości „uciskanych narodów” pracował razem ze swoim bratem Zhou Zuorenem. Część dzieł tłumaczyli wspólnie według następującego systemu: „Zhou Zuoren najpierw tłumaczył tekst ustnie, po czym Lu Xun zapisywał tekst literacką chińszczyzną" [Ding, Song 2020: 395]. Warto zaznaczyć, że język współczesny (potoczny) zaczęto wprowadzać do literatury chińskiej dopiero w Xx wieku. Wcześniej teksty literackie były zapisywane językiem klasycznym, używanym jedynie w piśmie, odmiennym gramatycznie i leksykalnie. W owym okresie przejściowym przekłady powstawały w obu tych językach. 
szenia dystansu między mentalnością Wschodu i Zachodu ${ }^{9}$ [Ding, Song 2020: 421]. To autorytet Lu Xuna wpłynął na kontynuowanie prac nad przekładami dzieł z Europy Środkowo-Wschodniej przez następne pokolenia badaczy.

Chociaż trzon tłumaczeń obcojęzycznych tekstów stanowiła w Chinach od początku literatura najbardziej wpływowych państw z kręgu kultury euroamerykańskiej ${ }^{10}$, to obecność twórczości polskiej i węgierskiej na tamtejszej scenie literackiej 1. połowy xx stulecia jest imponująca. W licznych czasopismach specjalistycznych oraz antologiach prozy zagranicznej pojawiały się utwory: Henryka Sienkiewicza, Stefana Żeromskiego, Bolesława Prusa, Władysława Reymonta, Elizy Orzeszkowej czy Marii Konopnickiej, a także szkice historycznoliterackie poświęcone polskim autorom. Większość z nich wyszła spod pióra Lu Xuna i jego brata Zhou Zuorena oraz Mao Duna, kontynuatora tradycji przedstawicieli Ruchu Nowej Kultury. Charakterystyczne dla tego okresu są przekłady niebezpośrednie ${ }^{11}$, gdyż żaden z wymienionych twórców nie posługiwał się polszczyzną. Tłumaczeń dokonywano przede wszystkim z języka angielskiego, francuskiego, niemieckiego i japońskiego. Lata 30. i 40. to z kolei czas, w którym ogromną rolę w popularyzacji obcej literatury odegrało esperanto [Ding, Song 2020: 476]. Język międzynarodowy umożliwił chińskim badaczom zapoznanie się z dziełami „słabych i niewielkich narodów”. Wielu z nich było aktywnymi działaczami ruchu esperantystów, a niektórzy dodatkowo sami tworzyli w lingvo internacia [Ding, Song 2020: 511-520].

Tłumaczeń bezpośrednich literatur Europy Środkowo-Wschodniej zaczęto dokonywać dopiero po powstaniu Chińskiej Republiki

9 Dopiero po klęskach w tzw. wojnach opiumowych (1839-1842, 1856-1860) nastąpił w Chinach koniec „polityki zamkniętych drzwi” i izolacji od kultury zachodniej [Ding, Song 2020: 247-248]. Z kolei upokorzenie w wojnie chińsko-japońskiej (1894-1895) „uświadomiło ówczesnym elitom istnienie naglącej potrzeby poznania zaawansowanej kultury Zachodu" [Ding, Song 2020: 421]. Wspomniane porażki militarne przyczyniły się do nadania temu okresowi (od lat 40. XIX wieku) miana „stulecia upokorzeń” [Ding, Song 2020: 18].

Zalicza się do nich: Wielką Brytanię, Francję, Niemcy, Rosję i Stany Zjednoczone. Ożywione kontakty literackie dotyczą również Japonii [Ding, Song 2020: 421-422]. 
Ludowej, kiedy w ramach współpracy między państwami socjalistycznymi rozpoczęły się wymiany studenckie. Zarówno w naszej ojczyźnie, jak i krajach sąsiednich kształcili się młodzi filolodzy z Chin, późniejsi tłumacze poszczególnych języków [Ding, Song 2020: 699]. Wysłani do Polski w 1954 roku Yi Lijun, Lin Hongliang i Zhang Zhenhui to wybitni seniorzy chińskiej polonistyki. Dorobek ich prac historycznoliterackich i translatorskich obejmuje setki pozycji, prezentujących rozległą panoramę twórczości polskich pisarzy $^{12}$. Wszyscy zostali uhonorowani Krzyżem Kawalerskim Orderu Zasługi RP, odznaką „Zasłużony dla Kultury Polskiej” oraz wieloma innymi nagrodami.

Przekładem, który zajmuje wyjątkowe miejsce na literackiej mapie Chin, jest trzecia część Dziadów, opublikowana w 1976 roku. Dramat Adama Mickiewicza był pierwszym zagranicznym dziełem literackim wydanym po zakończeniu rewolucji kulturalnejdziesięcioletnim okresie kulturowego spustoszenia i literackiego zastoju - w związku z czym krytycy okrzyknęli utwór „pierwszą jaskółką zwiastującą wiosnę”13 [Ding, Song 2020: 704]. Geneza chińskiego wydania wskazuje także na obecność Polski w ówczesnym dyskursie politycznym. Tłumaczenie zostało bowiem zlecone Yi Lijun przez samego premiera Zhou Enlaia, zaintrygowanego wydarzeniami marcowymi. Przywódcy Komunistycznej Partii Chin chcieli dowiedzieć się, na czym polega siła utworu odpowiedzialnego za masowe protesty i bunt przeciw represjom władzy, dlatego nakazali rozpocząć prace nad chińskojęzyczną wersją tekstu [zob. Wu, Zhang 2019].

Polska literatura przez długi czas funkcjonowała w Państwie Środka głównie w kontekście politycznym. Niezwykle trwałe

Są to przekłady m.in. arcydzieł: Pana Tadeusza, Dziadów, Krzyżaków, Trylogii, Quo vadis, Ziemi obiecanej, Ferdydurke, Lalki, powieści Olgi Tokarczuk; wyborów poezji: Adama Mickiewicza, Juliana Tuwima, Czesława Miłosza, Zbigniewa Herberta, Wisławy Szymborskiej, Tadeusza Różewicza, opowiadań: Henryka Sienkiewicza, Tadeusza Borowskiego, Zofii Nałkowskiej, Jarosława Iwaszkiewicza - i wielu innych [zob. Ding, Song 2020: 879-898].

13 Co znamienne, przekład powstawał w czasie, gdy jego tłumaczka doznawała bezpośrednich represji rewolucji. Yi Lijun pracowała nad nim w tajemnicy w czasie pobytu w obozie reedukacyjnym na prowincji, zmuszona, razem z innymi intelektualistami, do ciężkiej pracy fizycznej [zob. Yi Lijun laureatka... 2012]. 
okazało się dziedzictwo Lu Xuna, który zapoczątkował postrzeganie naszej ojczyzny jako reprezentanta uciśnionych nacji, stanowiących wzór patriotyzmu oraz przypisujących wysoką rangę twórczości artystycznej, bowiem w oczach Chińczyków „w tych «małych i słabych krajach wschodnioeuropejskich» literatura często jest symbolem dumy i szacunku narodu" [Li 2016: 183]. Przekładane dzieła były wybierane przede wszystkim pod kątem ich warstwy ideologicznej ${ }^{14}$, a jako najbardziej reprezentatywnych pisarzy promowano Mickiewicza i Sienkiewicza [Li 2016: 182-184]. Na wielką skalę zorganizowano w Chinach w 1955 roku obchody setnej rocznicy śmierci romantycznego poety, a artykuły poświęcone polskiemu wieszczowi ukazały się w głównych państwowych dziennikach [Li 2013: 143]. Z kolei Latarnik był pierwszym polskim utworem przetłumaczonym na język chiński ${ }^{15}$, inicjującym niesłabnące zainteresowanie dorobkiem Sienkiewicza. Noblista do dziś jest najbardziej rozpoznawalnym i najchętniej tłumaczonym polskim autorem. Najlepiej dowodzi tego fakt, że jak dotąd ukazało się w Państwie Środka aż 21 przekładów Quo vadis [Li 2016: 176].

Dopiero na początku XXI wieku zaczęto zwracać uwagę na współczesną literaturę polską oraz odbierać ją w oderwaniu od stereotypu narodowowyzwoleńczego [Li 2016: 182]. Przyczyniło się do tego $\mathrm{w}$ dużej mierze zainteresowanie polską poezją i nowymi noblistami: Czesławem Miłoszem i Wisławą Szymborską. O aktualnym oddziaływaniu twórczości Polaków na życie literackie w Chinach świadczą takie fakty, jak m.in. przyznanie Adamowi Zagajewskiemu w 2014 roku specjalnej nagrody poetyckiej ${ }^{16}$ [Ding, Song 2020: 962], a także przynależność opowiadania Poziomka Jarosława Iwaszkiewicza do kanonu lektur szkolnych (utwór poja-

14 Przykładowo po II wojnie światowej duży rozgłos zdobyły dzieła Leona Kruczkowskiego. Ich rewolucyjna i antyfaszystowska wymowa doskonale wpisała się w panującą w owym czasie w Chinach atmosferę triumfu [Li 2016: 173]. W latach 40. interesowano się z kolei twórczością komunistycznej działaczki Wandy Wasilewskiej [Ding, Song 2020: 473].

15 Wu Chou przełożył nowelę z języka japońskiego na chiński język klasyczny W 1906 roku [Li 2016: 172].

16 „Nagroda Poetycka Poezji i Człowieka” przyznawana przez czasopismo wskazane w nazwie wyróżnienia. 
wił się również jako jeden z tematów egzaminu wstępnego na studia wyższe [Li 2016: 177]).

Odmienne proporcje możemy zaobserwować w odniesieniu do recepcji literatury chińskiej w Polsce. Polskiemu czytelnikowi znane są przede wszystkim teksty popularnych współcześnie pisarzy, takich jak Mo Yan czy Yu Hua, i to ich twórczość stanowi główną reprezentację tłumaczeń z języka chińskiego. Dzieła, które zaliczylibyśmy do „klasyków” literatury Państwa Środka, nie są obecne w zbiorowej świadomości Polaków. Przekłady tradycyjnej twórczości literackiej czy mniej wypromowanych autorów powstały w wyniku działalności naukowej polskich sinologów i funkcjonują w obiegu znawców tej wąskiej dziedziny [zob. Ding, Song 2020: 738-745]. Trudno porównać skalę powstałych w tym środowisku tłumaczeń z osiągnięciami translatorskimi chińskich polonistów, gdyż w recenzowanej publikacji znajdziemy jedynie pojedyncze wzmianki na temat literatury Chin w odniesieniu do polskiego rynku wydawniczego.

Tom Chiny i Europa Środkowo-Wschodnia nie realizuje zatem w pełni celu, jaki postawili sobie autorzy serii. Zapowiedziany opis przebiegu dwukierunkowej wymiany kulturowej cechuje się dużą asymetrią. Z dwóch nadrzędnych pytań o to, jak Chiny współtworzyły literaturę zagraniczną i jak literatura światowa oddziaływała na twórczość pisarzy Państwa Środka [Ding, Song 2020: 38], o wiele obszerniej i bardziej szczegółowo zgłębiono to drugie. Postulowany „dwuoczny ogląd” wpłynął wprawdzie na naprzemienne odnoszenie się do źródeł chińskich i europejskich, lecz wielokrotnie nie poddawano dwustronnej analizie analogicznych zagadnień, trudno więc o bezpośrednie porównania ${ }^{17}$.

Fakt, że czytelnikowi znacznie szerzej zarysowuje się panoramę wpływu literatury środkowoeuropejskiej na literaturę chińską,

Zakres rozdziałów pisanych z perspektywy chińskiej i europejskiej jest każdorazowo nieco inny, np. Rozdziat XI. Sinologia, thumaczenia i publikacje na temat literatury chińskiej w Europie Środkowo-Wschodniej po 1949 roku, Rozdziat XII. Ttumaczenia, opracowania i badania literatury Europy Środkowo-Wschodniej po roku 1976 (cechuje je również całkowicie odmienny układ treści). Z kolei rozdział ostatni, Najważniejsi tlumacze i badacze literatury Europy Środkowo-Wschodniej, w ogóle nie ma „lustrzanego” odpowiednika. 
wynika z oczywistych ograniczeń autorów tomu, którzy nie byli w stanie korzystać w jednakowym stopniu z rodzimych i obcojęzycznych opracowań i jak sami zaznaczają, podjęli się opisania kwestii w dużej mierze niezbadanych ${ }^{18}$ [Ding, Song 2020: 965]. Ponadto zadanie równoczesnego omówienia dorobku 16 różnych państw samo w sobie jest obciążone ryzykiem dysproporcji i skrótowości. Zakładane dwustronne spojrzenie na wymianę kulturową cechuje się zatem wyraźną dominacją perspektywy chińskiej, co według twórców jest naturalnym wynikiem opracowania zagadnienia przez badaczy reprezentujących ów region świata [Ding, Song 2020: 38]. Niemniej podczas lektury tekstu można odnieść wrażenie pewnego dysonansu pomiędzy przedstawionymi na wstępie ideami a ostatecznym kształtem kompendium, gdyż zdawkowe informacje o najmniejszych europejskich krajach oraz ujęcie różnorodnych narodów jako jednej, względnie tożsamej, grupy może uwypuklać punkt widzenia podmiotu-hegemona. Co ciekawe, podkreślane w prezentacji modelu badawczego odejście od „hegemonii pojedynczego państwa, regionu czy języka” [Ding, Song 2020: 37] nawiązywało przede wszystkim do marginalizacji literatury chińskiej w zachodniocentrycznym kanonie literatury światowej ${ }^{19}$ [zob. Ding, Song 2020: 44-45].

Przyjęcie określonej perspektywy badawczej daje za to polskiemu czytelnikowi rzadką możliwość spojrzenia na swój kraj i jego twórczość z chińskiego punktu widzenia ${ }^{20}$. Zauważamy, że autorzy mieli przede wszystkim na uwadze rodzimego odbiorcę,

O niedoskonałościach tomu autorzy piszą w Posłowiu: „Zagadnienie kontaktów i wymiany literackiej między Chinami a Państwami Europy Środkowo-Wschodniej dotyka różnych języków i informacji porozrzucanych po bezkresnym morzu książek [...]. Ze względu na ograniczenia językowe i źródłowe część przedstawiająca recepcję literatury chińskiej w Europie Środkowo-Wschodniej wydaje się najsłabsza" [Ding, Song 2020: 969].

Twórcy w następujący sposób postrzegają pozycję rodzimej literatury: „Możemy np. napisać jedną książkę o wpływie literatury chińskiej na literaturę zachodnią, ale wpływ literatury zachodniej na współczesną literaturę chińską jest tak przemożny, że przekłada się on niemal na całą jej historię. A zatem pisanie «ze stanowiska chińskiego» jest już samo w sobie rodzajem «pisania od drugiej strony» (write back)" [Ding, Song 2020: 44-45].

Do takiego wniosku dochodzą autorzy polskojęzycznej wersji tekstu [zob. Religa 2020]. 
dlatego też niektóre informacje zawarte w tomie mogą wydawać się Europejczykowi zbyt oczywiste. Należy jednak pamiętać, że historia czy geografia mniej liczącego się na arenie międzynarodowej regionu Starego Kontynentu może być dla mieszkańca jednego z największych państw na świecie zupełnie obca. Mimo wszystko trudno czasami oprzeć się wrażeniu zbyt uproszczonego i uogólniającego traktowania zjawisk z obszaru środkowoeuropejskiego. Przykładowo na kilku stronach omawia się rozwój literatur wszystkich krajów badanego rejonu ${ }^{21}$, wymieniając dość chaotycznie przykładowe dzieła i sprowadzając je do wspólnego mianownika. Wątpliwość budzi ujednolicanie wielu zagadnień i formułowanie powierzchownych wniosków w rodzaju: „Literatura w krajach Europy Środkowo-Wschodniej zawsze wysuwała na pierwszy plan dziedzictwo narodowe i rozwój tradycji, podkreślając narodową tożsamość” [Ding, Song 2020: 82]. Szczególnie po obszernym omówieniu założeń przedsięwzięcia, które miało na celu analizę wzajemnych wpływów, można było spodziewać się bardziej pogłębionych rozważań z zakresu literatury i sztuki. $\mathrm{Z}$ dozą rozczarowania odkrywamy, że autorzy publikacji przyjęli przede wszystkim ton sprawozdawczy, referujący określone fakty historyczne i kulturowe, a niektóre rozdziały mają charakter ściśle kronikarski czy też bibliograficzny ${ }^{22}$. Nie uniknęli także pewnych nieścisłości i błędów rzeczowych, skorygowanych w przypisach tłumaczy ${ }^{23}$, słusznie doceniających, mimo drobnych usterek, walor poznawczy książki. Jak stwierdza Małgorzata Religa:

[...] już sama ilość i różnorodność zawartych tu informacji jest imponująca, a ich zakres czasowy ogromny - obejmuje około dwóch tysięcy lat od najwcześniejszych kontaktów między Azją a Europą Środkową aż do dziś. [Religa 2020: 15] Na przykład ostatni rozdział, w którym wymienieni są współcześni tłumacze i badacze literatury Europy Środkowo-Wschodniej oraz ich dzieła, lub podrozdział poświęcony początkom sinologii w wybranych krajach europejskich. Przykładowo we wprowadzeniu pojawia się informacja, że pierwszym laureatem Nagrody Nobla z Polski (i generalnie Europy Środkowo-Wschodniej) był Władysław Reymont [Ding, Song 2020: 81]. 
Na wielkie uznanie zasługuje praca autorów przekładu: Rafała Darasza, Artura Ganczarskiego, Kazimierza Michalika, Łukasza Mrugały, Michała Nity i Pauliny Uznańskiej². Stawali oni niejednokrotnie przed problemami związanymi z dotarciem do wymienianych w tomie materiałów źródłowych i ustaleniem ich polskojęzycznego odpowiednika, gdyż nazwy własne zapisane chińskimi znakami, będące częstokroć wynikiem wolnego tłumaczenia, utrudniały bądź uniemożliwiały identyfikację dzieł, osób czy miejsc, do których się odnosiły. Tłumacze ze szczególną dokładnością komentowali i rozszerzali wywód chińskich autorów tak, by możliwie najlepiej przybliżyć polskiemu czytelnikowi obcą perspektywę i realia Państwa Środka. We wstępie redakcja zamieściła skrótowe przedstawienie najważniejszych wydarzeń historycznych i postaci literackich dalekowschodniego mocarstwa, co ułatwia odbiorcy zrozumienie kontekstu prowadzonych rozważań. Tłumacze dużą wagę przywiązywali także do oddania specyficznej retoryki chińskich badaczy, obarczonej określonym ideologicznym nastawieniem. Jak zaznaczyli zagraniczni literaturoznawcy, w swych dociekaniach badawczych pozostali wierni "materializmowi dialektycznemu i materializmowi historycznemu” [Ding, Song 2020: 965]. Uwagę zwracają również fragmenty zapisane charakterystycznym stylem literackim, reprezentatywnym dla chińskiej estetyki. W następujący sposób zaprezentowano np. rejon Europy Środkowo-Wschodniej:

Znajdują się tu łagodnie wznoszące się wyżyny, a także majestatyczne Karpaty porośnięte iglastym lasem. Szumiące sosny, świerki i modrzewie wznoszą się ku niebu. Król rzek, błękitny Dunaj o rozśpiewanych falach, pędzi niepowstrzymanie na Wschód. Są tu rozsiane jak gwiazdy jeziora, urokliwe i pełne czaru, każde inne od drugiego. Są tu połacie fioletowej lawendy i czerwone maki, są tu spokojne wioski, przepiękne pałace i owiane tajemnicą zamki, strzeliste kościoły, posągi lwów i kawiarnie przy uliczkach i na miejskich skwerach, a wszystko to jest pełne uroku przeszłości i przesiąknięte 
pięknem harmonii między Naturą i człowiekiem. [Ding, Song 2020: 74]

Ostatnie lata to czas powrotu pamięcią do kilku istotnych wydarzeń, które prowokują próbę podsumowania oraz oceny kontaktów Chin i Polski. Jeśli przyjmiemy perspektywę szeroką, możemy stwierdzić, że minęło już 800 lat od momentu, gdy „Benedykt Polak po raz pierwszy postawił stopę na chińskiej ziemi” [Ding, Song 2020: 957-958]. Z kolei w 2019 roku obchodziliśmy 70. rocznicę nawiązania stosunków dyplomatycznych między wspomnianymi państwami, a także 65. rocznicę powstania katedry języka polskiego na Pekińskim Uniwersytecie Języków Obcych [Wu, Zhang 2019]. Lektura historii kontaktów literackich pozwala wysnuć wniosek, że w badanym zakresie czasowym to strona chińska wykazała się wyjątkową dbałością o wzajemne poznanie. Wśród tamtejszej inteligencji, zwłaszcza xx-wiecznej, ukształtował się bardzo emocjonalny, braterski stosunek do narodu polskiego oraz przekonanie, iż „podobne doświadczenie i usytuowanie historyczne powoduje, że literatura polska ma dla Chin szczególne znaczenie" [Li 2016: 184]. Na tym polu ujawnia się nierówność wymiany kulturowej, trudno bowiem byłoby w analogiczny sposób skomentować funkcjonowanie literatury chińskiej w Polsce:

Kiedy w Chinach mówimy o literaturze polskiej, zawsze nasuwają się nazwiska: H. Sienkiewicza i W. Reymonta jako powieściopisarzy, J. Iwaszkiewicza jako eseisty, R. Kapuścińskiego jako reportażysty, E. Orzeszkowej i O. Tokarczuk jako reprezentantek literatury kobiecej. [Li 2016: 176]

Wydaje się zatem, że Chińczycy mają większą wiedzę o twórczości Polaków niż Polacy o literackich dokonaniach Chińczyków. Nie bez znaczenia pozostaje jednak fakt, że w Chinach przez długi czas prace nad przekładami miały charakter ideologiczny, wynikały z określonych założeń i planów politycznych, a co za tym idzie, były wspierane przez organy władzy [Ding, Song 2020: 696]. Do dziś promocja literatury naszego regionu odbywa się dzięki państwowym programom dofinansowań, które umożliwily wydanie 
zaplanowanej na 100 pozycji serii Niebieska Europa Wschodnia ${ }^{25}$ [Ding, Song 2020: 961].

Mimo pewnych nierówności można stwierdzić, że polsko-chińskie kontakty literackie są aktywnie rozwijane, o czym świadczy chociażby opracowanie tłumaczenia omawianego tomu zaledwie kilka lat po jego publikacji. Został on wydany w 2016 roku, ogłoszonym w Chinach rokiem wymiany w dziedzinie humanistyki z Europą Środkowo-Wschodnią [Ding, Song 2020: 970]. W tym czasie podjęto wiele inicjatyw promujących polską literaturę, m.in. zrealizowano słuchowisko Krzyżacy z udziałem chińskich aktorów, któremu towarzyszyły dwa koncerty Krzyżacy China Live [„Krzyżacy” po chińsku... 2016]. Rok wcześniej na deskach pekińskiego teatru kilkukrotnie wystąpił zespół Michała Zadary $\mathrm{z}$ inscenizacją Dziadów, a wydarzenie połączone było z premierą pierwszego pełnego przekładu dramatu ${ }^{26}$. Polska sztuka spotyka się w Państwie Środka z bardzo dobrym odbiorem, a między twórczością i doświadczeniem tych pozornie zupełnie różnych narodów odkrywa się zaskakujące związki. Jak wskazuje polonistka Li Yinan [2013: 137]: „[... ] podobnie do tragicznego losu Polski pod zaborami pierwsza wojna opiumowa to początek rozbicia i okupacji ówczesnych Chin”. Zaznacza też, że niezwykłą popularność zyskała wśród Chińczyków Grażyna. Tytułowa postać poematu Mickiewicza przypominała dalekowschodnią bohaterkę legendy Mulan [Li 2013: 143]. Adaptacja polskich dzieł i wątków do chińskiego paradygmatu kulturowego przedstawiona w tomie Chiny i Europa Środkowo-Wschodnia dowodzi po raz kolejny, że pisarzom zawdzięczamy uniwersalne medium dialogu. Potwierdza też słowa wielkiego Lu Xuna, iż „najkrótsza droga do wzajemnego zrozumienia wiedzie przez literaturę i sztukę" [Ding, Song 2020: 572].

Nazwa serii ma wskazywać na uwolnienie literatury wschodnioeuropejskiej od stereotypowego skojarzenia z „czerwonymi klasykami” [Ding, Song 2020: 944]. Stworzonego przez wspomniane trio badaczy: Yi Lijun, Lin Honglianga i Zhang Zhenhuia. 


\section{Bibliografia}

Ding Chao, Song Binghui (2020), Chiny i Europa Środkowo-Wschodnia. Historia kontaktów literackich [e-book; format PDF], red. nauk. Małgorzata Religa, Wydawnictwo Akademickie Dialog, Warszawa. Kulczycki Emanuel (2007), Utopia języka doskonatego w europejskim kręgu kulturowym, „Homo Communicativus”, nr 2, s. 65-77. „Krzyżacy” po chińsku w Państwie Środka (2016), [dostęp: 15 listopada 2020], https://tinyurl.com/4mhecsbw.

Li Yinan (2013), Literatura polska w Chinach: historia przekładów, „Azja Pacyfik: Społeczeństwo - Polityka - Gospodarka”, t. 16, s. 132-157.

Li Yinan (2016), Recepcja literatury polskiej w Chinach: teoria i dzieje, „Postscriptum Polonistyczne”, nr 2, s. 171-185.

Religa Małgorzata (2020), Wstęp do wydania polskiego, w: Ding Chao, Song Binghui, Chiny i Europa Środkowo-Wschodnia. Historia kontaktów literackich [e-book; format PDF], red. nauk. Małgorzata Religa, Wydawnictwo Akademickie Dialog, Warszawa, s. 14-23.

Wu Yu, Zhang Shuo (2019), Arcydzieła literatury polskiej łącznikiem relacji Chiny - Polska, [dostęp: 15 listopada 2020], https://tinyurl.com/ fdw8dhsp.

Yi Lijun laureatką Transatlantyku 2012 (2012), [dostęp: 15 listopada 2020], https://tinyurl.com/5ckstyy2.

Karolina Galewska

\section{Great Art of a Tiny Nation: Poland in the Context of China's Literary Contacts with Central and Eastern Europe}

In 2020, Wydawnictwo Akademickie Dialog published the Polish version of Chiny i Europa Środkowo-Wschodnia. Historia kontaktów literackich (China and Central and Eastern Europe. The History of Literary Contacts) by Chinese literary scholars: Ding Chao and Song Binghui. The book is part of the series Historia Kontaktów Literackich między Chinami a Zagranica (The History of China's Foreign Literary Contacts) which aims to become a comprehensive description of China's cultural exchange with other countries. Volume 17 is devoted to China's relationships with Albania, Bosnia and Herzegovina, Bulgaria, Croatia, Czechia, Estonia, Hungary, Lithuania, Latvia, Montenegro, North Macedonia, Poland, Romania, Serbia, Slovakia and Slovenia. In this group, Poland occupies one of the central positions due to, among other, a high interest in Polish history among Chinese intellectual elite of the early twentieth century and among the reformers of Chinese literature in that period. The article discusses the sources of the popularity of Polish themes in the formative period of modern Chinese literature and the 
reception of Polish literature in China today. It also attempts to familiarise the readers with the themes studied by the researchers, the goals they set for themselves and the methods they used to achieve them, and presents the benefits of publishing the book in Polish.

Keywords: China; Central and Eastern Europe; Chinese literature; Polish literature; literary contacts; literary translation.

Karolina Galewska - językoznawczyni, lektorka języka polskiego jako obcego, doktorantka w Szkole Doktorskiej UAM, związana z Pracownią Leksykologii i Logopedii w Instytucie Filologii Polskiej. Zajmuje się przede wszystkim onomastyką, zwłaszcza w perspektywie porównawczej. Bada nazwy polskie, angielskie i chińskie, poświęcając uwagę m.in. zagadnieniom przekładu pomiędzy językami z kręgu kultury europejskiej oraz dalekowschodniej. 